\title{
Cryptosporidiosis in Colombian children with HIVIAIDS infection
}

\author{
Carlos Alberto Velasco, MD², Fabián Méndez, MD, PhD², Pío López, MD³
}

\section{SUMMARY}

Introduction: Enteric cryptosporidiosis in children with HIV/AIDS is an important cause of morbidity and mortality.

Objective: To determine the prevalence of Cryptosporidium spp. in feces, via the Ziehl Neelsen modified technique, among Colombian children with HIV/AIDS and to determine possible associations.

Methodology: Prevalence study in 131 children with HIV/AIDS at the Hospital Universitario del Valle in Cali, Colombia. We evaluated clinical records, laboratory results, environmental factors, and socio-demographic variables. Statistical analysis included the estimation of prevalence of infection in children and the corresponding 95\% confidence interval; estimation of other descriptive conditions of interest and the association analyses by multiple logistic regression.

Results: In this group of children with a mean age of 57 months, we found a prevalence of infection of $29 \%$, more frequently among male children and among those with vertical HIV transmission. The infection was also associated with abdominal pain, having pets inside the house and C stage for $\mathrm{HIV}$, with $\geq 100,000 \mathrm{copies} / \mathrm{ml}$ of viral load and CD4 percentage $\geq 25 \%$. Association analysis showed a larger risk of Cryptosporidium infection with older age, and among patients not living in Cali, with more severe status of HIV disease, previous hospitalizations, and dried oral mucosa. Factors found finally associated were older age, chronic undernutrition, living in day-care institutions and having previous hospitalizations.

Conclusion: Almost a third of these children patients had Cryptosporidium infection, and it was found associated with age, previous hospitalizations, chronic undernutrition and living in day-care institutions.

Keywords: Cryptosporidium spp; Prevalence; HIV/AIDS infection; Children.

Colomb Med. 2011; 42: 418-29

\section{Criptosporidiosis en niños colombianos con infección por VIH/SIDA}

\section{RESUMEN}

Introducción: La criptosporidiosis entérica en niños infectados por VIH es una causa importante de enfermedad y muerte. Objetivo: Determinar la prevalencia de Cryptosporidium spp. en heces por medio de la técnica de Ziehl Neelsen modificada, en niños colombianos con infección por VIH/SIDA y establecer posibles asociaciones.

Metodología: Estudio de prevalencia en 131 niños con infección por VIH/SIDA. Fueron consideradas variables clínicas, paraclínicas, ambientales y sociodemográficas. El análisis estadístico incluyó estimación de la prevalencia de infección en los niños y su correspondiente intervalo de confianza al 95\%, la estimación de otras medidas descriptivas de interés y el análisis de asociación por regresión logística múltiple.

Resultados: En esta población de niños con una edad promedio de 57 meses se encontró una prevalencia de 29\% de infección, predominio del sexo masculino y el modo de transmisión vertical en VIH. La infección se asoció además con dolor abdominal, tenencia de animales en el intradomicilio y a estadio C para VIH, con $\geq 100.000$ copias/ml de carga viral y porcentaje de CD4 $\geq 25 \%$. En el análisis de asociación se encontró mayor oportunidad de infección por Cryptosporidium a mayor edad, en los pacientes de fuera de Cali, con mayor severidad del estadío para VIH, con hospitalizaciones previas, y con mucosa oral seca. Los factores finalmente asociados fueron la mayor edad, la DNT crónica, la convivencia en guarderías

1. Professor, Director Research Group GASTROHNUP, Faculty of Health, Universidad del Valle, Cali, Colombia. e-mail: carlos.velasco@correounivalle.edu.co

2. Assistant Professor and Head of the School of Public Health, Director Research Group GESP, Faculty of Health, Universidad del Valle, Cali, Colombia. e-mail: fmendez@grupogesp.org

3. Professor, Director Pediatric Research Center, Faculty of Health, Universidad del Valle, Cali, Colombia. e-mail: piolo@emcali.net.co

Received for publication April 20, 2010 Accepted for publication September 14, 2010 
y las hospitalizaciones previas.

Conclusión: Casi una tercera parte de los pacientes presentaron infección y esta se encontró asociada con la edad del niño, con hospitalizaciones previas, con convivencia en guarderías y DNT crónica.

Palabras clave: Cryptosporidium spp; Prevalencia; Infección por VIH/SIDA; Niños.

Colomb Med. 2011; 42: 418-29

Cryptosporidium has been reported for causing disease in humans since 1976. It is an important cause of diarrhea in children with and without HIV infection in developing countries, where the infection at early ages has been reportedly associated to stunted physical and cognitive growth ${ }^{1}$. In our experience, prevalence of Cryptosporidium among immunocompetent children varies between $4 \%$ and $32.3 \%$, while among immunocompromised children it reaches values between 42 and $51.4 \%{ }^{2,3}$. In particular, a study in Medellín, Colombia, among 103 patients, 2-74 years of age, found $39.8 \%$ prevalence for Cryptosporidium spp. This was the first study in Colombia, which achieved the identification of C. hominis, C. parvum, and C. felis ${ }^{4}$.

Cryptosporidiosis is frequently associated to persistent diarrhea disease (PDD) and undernutrition (UNT) in immunologically compromised individuals, like those with HIV/AIDS infection, in whom therapy has not been effective ${ }^{5}$. However, it is also a serious frequent cause of acute diarrhea disease (ADD) at all ages of immunologically healthy individuals ${ }^{6}$. Until the introduction of antiretroviral therapy (ART) between 1995 and 1996, it was a serious opportunistic infection, which complicated HIV/AIDS infection. In immunocompetent children, enteric cryptosporidiosis by $C$. parvum induces light and self-limited gastroenteritis, while in HIV-infected children it is severe, with dehydration (DHT), and is associated to massive loss of liquids ${ }^{6}$. Risk of infection is closely related to immune disorders, mainly low count of CD4+ cells, and the severity of the symptoms is associated to the number of oocysts ${ }^{7}$. Although the therapeutic treatment is yet unclear, the use of macrolides and thiazolides is an alternative. Among children with HIV/AIDS infection, the prevalence of Cryptosporidium spp. varies between $8 \%$ in the United States ${ }^{7}$ and $73.6 \%$ in Uganda ${ }^{4}$, with a frequency of $<1.0$ per 100 individuals per year ${ }^{8,9}$. In our experience, the prevalence of Cryptosporidium spp. in feces via the modified Zielh Neelsen (ZN) technique, in immunocompetent children from the municipality of Piedecuesta in Santander was of 32.3\% and only 4.0\% in the city of Cali in Valle del Cauca. Among immunecompromised children with cancer at the Hospital Universitario de Santander in the city of Bucaramanga, in northeastern Colombia, the prevalence was $42 \%$, while among children with HIV/AIDS infection Hospital Universitario del Valle in the city of Cali, in the southwest region of the country, it was 51.4\% (95\% confidence interval CI: 39.9-62.9) $)^{2,3}$.

Little is known, however, about local risk factors associated to this common cause of morbidity and mortality among patients with immune disorders. Our general objective was to determine the prevalence of Cryptosporidium spp. in feces, via the modified ZN technique, among a group of Colombian children with HIV/AIDS infection under highly active antiretroviral therapy (HAART), and to evaluate possible association with socio-demographic, clinical, paraclinical, and environmental factors.

\section{METHODOLOGY}

A prevalence study was conducted among children below 15 years of age diagnosed with HIV/AIDS infection and attending the HIV/AIDS Pediatric Clinic at the «Hospital Universitario del Valle Evaristo García» (HUV) in Cali, Colombia between February and April, 2009. We determined the presence and risk factors for Cryptosporidium spp. infection without considering seasonal climate changes, although they are well known to influence presence of Cryptosporidium spp., especially after rainy seasons ${ }^{10}$ and in tropical regions, like in our study area ${ }^{13}$. The target population was children from the Colombian southwest and under treatment or observation. The study included both male and female children, $<15$ years of age, diagnosed with HIV/AIDS infection through positive ELISA test, positive confirming Western blot test, and positive viral load (these tests taken at least 15 days before or after taking feces to identify Cryptosporidium spp.). Also, to be included, children must not have taken antiparasitic medications like nitazoxanide, corticosteroids or antibiotics like azithromycin or paromomycin, 15 days prior to the determination of the Cryptosporidium 
spp. in feces. We excluded children with other confirmed immunodeficiency and patients hospitalized because of diseases concomitant to HIV/AIDS infection, which place their lives at risk, like septic shock, severe hydroelectrolyte or acid-alkaline imbalances. Assuming an expected prevalence of $51 \%$, with an estimation error of $\pm 5 \%$, and an $\alpha$ error of 0.05 , a total population from the HIV/AIDS Pediatric Clinic at HUV of 161 children with HIV/AIDS infection by December 31, 2008, and a $15 \%$ adjustment of losses of samples from the children, or of no response, the sample size was of 131 children.

The main exposures of interest were the viral load and the percentage of CD4 cells; while the evaluated socio-demographic variables were age, gender, background, HIV mode of transmission; and the clinical variables included the nutritional status (weight, height, global undernutrition, chronic undernutrition, acute undernutrition, overweight), gastrointestinal signs and symptoms (acute diarrhea, chronic diarrhea, vomit, abdominal pain, abdominal distension, enophthalmos, acidotic breathing, distal perfusion, weeping without tears, abdominal fold, dry oral mucosa), general symptoms (fever), stage of HIV/AIDS infection, hospitalizations; the paraclinical variables: viral load for HIV, percentage of CD4, and environmental variables: household pets, consumption of potable water, excreta disposal, overcrowding, stay in day-care center. The result variable was the identification of Cryptosporidium spp. in at least one of the three slides of the fresh feces samples collected, and processed via the modified $\mathrm{ZN}$ technique ${ }^{14}$ one to three days after interviewing each child in the study.

This work was approved by the Ethics Committee at Universidad del Valle and at the HUV in Cali, Colombia. The children's parents or legal guardians who accepted to participate signed a written informed consent and answered a structured questionnaire applied by the main researcher. After the survey, and during three consecutive days, a fresh collection of fecal matter was obtained labeled with non-sequential random numbers and handed over to one of the two microbiology bacteriologists who divided the sample on three slides. The initial diagnosis of enteric cryptosporidiosis by Cryptosporidium spp. was conducted on the fresh collection sample of fecal matter from which three extends were obtained through fixation and concentration, via the modified $\mathrm{ZN}$ technique by the two microbiology bacteriologists. The plates were revised individually and separately by each of the two microbiology bacteriologists; and in case of discrepant results these were again checked to give a joint final concerted verdict.

The database was in EpiInfo 6.04 and statistical analysis was performed with Stata 10 . To evaluate the possibility of typing errors, $10 \%$ of the records were checked and compared with the original forms and corrected accordingly. To describe the distribution of variables, exploratory analysis was performed of all the variables. For the continuous variables, we obtained plots (histograms, box and whisker plots, symmetry plots), which permitted describing their distribution, as well as the central tendency and dispersion measurements. An analysis of normality was done and, if needed, we developed data transformations for their normalization. For categorical variables, we obtained frequencies and proportions.

The HIV viral load variable was defined according to four categories (<400 copies/ml; 401 and 29,999 copies/ml; 30,000 and 99,999 copies/ml; and $\geq 100,000$ copies/ml), and the CD4 percentage was divided into three categories ( $<15 \%, 15$ and $24 \%$, and $\geq 25 \%)$.

The nutritional status of the children of the study was established by using reference tables from the United States National Center for Health and Statistics and the classifications by Gómez and Waterlow for global undernutrition (UNT) according to weight for age $\left(1^{\text {st }}\right.$ degree or light $=10-24 \%$ deficit; $2^{\text {nd }}$ degree or moderate $=25-39 \%$ deficit; and $3^{\text {rd }}$ degree or severe $=$ $>40 \%$ deficit); chronic UNT according to height for age $\left(1^{\text {st }}\right.$ degree or light $=5-9 \% ; 2^{\text {nd }}$ degree or moderate $=10$ $14 \%$; and $3^{\text {rd }}$ degree or severe $\geq 15 \%$ deficit); and acute UNT according to weight for height ( $1^{\text {st }}$ degree or light $=10-19 \%, 2^{\text {nd }}$ degree or moderate $=20-29 \%$, and $3^{\text {rd }}$ degree or severe $\geq 30 \%$ deficit). Overweight was defined as a $>10 \%$ weight for height excess.

We estimated the proportion of children with infection with its corresponding 95\% confidence interval (CI); and the descriptive measurements with their corresponding standard deviations and ranges. To evaluate infection risk factors, a univariate analysis was initially performed between each of the exposure variables of interest and the effect variable. We also explored the possible association among the exposure variables of greater interest (viral load and percentage 
of CD4) and other co-variables and between infection by Cryptosporidium and the rest of the co-variables to evaluate confounding. Odds ratios (OR) were estimated with 95\% CI, and statistical significance was evaluated with Fisher's exact test. For confounding and interaction evaluation, we performed multiple logistic regression analyses. To guide in obtaining the final multiple logistic regression model, we used a backward stepwise methodology with a probability of retirement of 0.10 .

\section{RESULTS}

Between February and April of 2009, 161 children were eligible and 131 were finally included in the study. Some missing data was not available for some children with information of weight for height nutritional status $(n=5)$, viral load $(n=1)$, and CD4 percentage $(n=8)$.

Among 38 children, at least one of corresponding three examined slides were found positive for Cryptosporidium spp. (prevalence of infection 29\%; 95\%CI: 21.2-36.8), and they are considered as cases for further analysis, while children with all three negative samples $(n=93)$ are considered controls. Table 1 describes main characteristics of the study group. The average weight was $15.2 \pm 7.7 \mathrm{~kg}$ (range of 4.1-45 kg); average height was $96 \pm 22 \mathrm{~cm}$ (range of $54-165 \mathrm{~cm}$ ); and $77.9 \%$ [CI 95\% (70.8-85\%)] of the children had been hospitalized at least once after HIV/AIDS diagnosis. The average viral load was 302,414 $\pm 364,962$ copies/ml (range of $39-1$ '500,000 copies/ml) and the mean percentage of CD4 was $27 \% \pm 13 \%$ (range of $2 \%-74 \%$ ).

Association analysis. We found higher odds of Cryptosporidium infection among older and male children among those not living in Cali, with acute UNT, in children presenting fever, dry oral mucosa, weeping without tears, with a more severe stage of disease, previous hospitalizations, and among those children staying in day-care centers. Conversely, lower odds of infection were found with global UNT, chronic UNT, higher viral load, and lower CD4 percentage (Table 2).

After controlling for potential confounders, the variables best explaining the presence of Cryptosporidium spp. were age, chronic UNT, stay in day-care centers, and prior hospitalizations (Table 3), even when the paraclinical variables, viral load and percentage of CD4, were also included in the analysis (Table 4).

\section{DISCUSSION}

Various studies have evaluated the occurrence of Cryptosporidium spp. in HIV-positive children. The study by Dankner et al., included 3331 HIV positive children in 13 clinical trials before HAART with an average follow-up of 23.8 months and found 0.6 Cryptosporidium spp. infections per 100 child-years (CI 95\% 0.4-0.8) ${ }^{8}$. According to Tumwine et al. ${ }^{6}$, there is 44.4 times greater odds (CI 95\% 18.4-110.4p $<0.0001$ ) of presenting Cryptosporidium spp. in HIV-positive children as compared to HIV-negative children. In the current study, we found a $29.0 \%$ prevalence of Cryptosporidium in feces using the modified $\mathrm{ZN}$ technique, and our result is similar to the report by Amadi et al. ${ }^{15}$, which identified a $28.84 \%$ prevalence of Cryptosporidium spp. in 104 HIV-positive children from Zambia. Additionally, they found a diagnosis of persistent undernutrition-diarrhea syndrome, suggesting a high prevalence of intestinal infectious disease, and underpinning the importance of cryptosporidiosis as a contributing factor in the physiopathology of this syndrome.

Our prevalence triplicates that reported by Guarino et al. ${ }^{7}$, who identified the presence of Cryptosporidium spp. in 3 of 35 North American HIV-positive children with diarrhea (8.6\% prevalence); and who unlike our study, identified Cryptosporidium spp. in $85 \%$ of feces samples via immunofluorescence and only in $15 \%$ with the modified $\mathrm{ZN}$ technique, which allows them to conclude that enteric cryptosporidiosis is a severe problem during advanced stages of HIV/AIDS infection. Likewise, our prevalence doubles that reported by Cegielski et al. ${ }^{5}$, of $13 \%$ in 3 of 23 HIV-positive children from Tanzania with chronic diarrhea who unlike our study - identified Cryptosporidium spp. via Kinyoun stain and monoclonal antibodies through direct fluorescence; thus, for these authors, Cryptosporidium spp. was considered an important pathogen in children with chronic diarrhea and HIV/AIDS infection. Finally, our prevalence is low, compared to the results by Tumwine et al. ${ }^{6}$, in Uganda who reported $73.6 \%$ Cryptosporidium spp., unlike our study, via immunofluorescence and PCR in feces of 91 HIV-positive children with persistent diarrhea and without antiretroviral therapy, which (in part) for them could explain the very high prevalence of this parasite in this 
Table 1

General characteristics of children with HIVIAIDS infection.

Hospital Universitario del Valle, Cali, Colombia 2008 ( $n=131)$

\begin{tabular}{|c|c|c|c|c|}
\hline & $\begin{array}{c}\text { All } \\
(n=131)\end{array}$ & $\begin{array}{c}\begin{array}{c}\text { Cases } \\
(\mathrm{n}=38)\end{array} \\
\text { C. spp. }+\end{array}$ & $\begin{array}{c}\text { Controls } \\
(n=93) \\
\text { C. spp. - }\end{array}$ & $\mathbf{p}$ \\
\hline Age (months) & $\begin{array}{c}57.0 \pm 41.3 \\
(1-173)\end{array}$ & $\begin{array}{c}68.3 \pm 41.6 \\
(13-170)\end{array}$ & $\begin{array}{c}52.4 \pm 40.4 \\
(1-173)\end{array}$ & 0.08 \\
\hline \multicolumn{5}{|l|}{ Gender $(n, \%)$} \\
\hline Male & $69(52.7)$ & $19(50.0)$ & $50(53.8)$ & \\
\hline Female & $62(47.3)$ & $19(50.0)$ & $43(47.2)$ & 0.69 \\
\hline \multicolumn{5}{|l|}{ Place of origin $(n, \%)$} \\
\hline Cali & $56(42.7)$ & $37(39.8)$ & $19(50.0)$ & \\
\hline Valle & $40(30.5)$ & 31 (33.3) & $9(23.7)$ & \\
\hline Other & $35(26.7)$ & $25(26.9)$ & $10(26.3)$ & 0.28 \\
\hline \multicolumn{5}{|c|}{ Mode of transmission $(n, \%)$} \\
\hline Vertical & $126(96-18)$ & $38(100)$ & $88(94-62)$ & \\
\hline Sexual & $3(2.3)$ & 0 & $3(3.2)$ & \\
\hline Transfusion & $2(1.5)$ & 0 & $2(2.2)$ & 0.36 \\
\hline \multicolumn{5}{|l|}{ Stage $(n, \%)$} \\
\hline A & $34(25.9)$ & $9(23.7)$ & $25(26.9)$ & \\
\hline B & $33(25.2)$ & $6(15.8)$ & $27(29.0)$ & \\
\hline C & $64(48.8)$ & $23(60.5)$ & $41(44.1)$ & \\
\hline \multicolumn{5}{|c|}{ Signs and symptoms $(n, \%)$} \\
\hline Abdominal pain & $19(14.5)$ & $5(13.2)$ & $14(15.1)$ & 0.77 \\
\hline Abdominal distension & $16(12.2)$ & $3(7.9)$ & $13(13.9)$ & 0.33 \\
\hline Acute diarrhea & $13(9.9)$ & $3(7.9)$ & $10(10.7)$ & 0.33 \\
\hline Fever & $13(9.9)$ & $4(10.5)$ & $9(9.7)$ & 0.88 \\
\hline Vomit & $9(6.9)$ & 0 & $9(9.7)$ & 0.11 \\
\hline Dry oral mucosa & $4(3.1)$ & $2(5.3)$ & $2(2.2)$ & 0.34 \\
\hline Chronic diarrhea & $3(2.3)$ & 0 & $3(3.2)$ & 0.33 \\
\hline Presence of tears & $3(2.3)$ & $1(2.6)$ & $2(2.2)$ & 0.86 \\
\hline Enophthalmos & $2(1.5)$ & - & $2(2.2)$ & 0.83 \\
\hline Distal malperfusion & $1(0.8)$ & - & $1(1.1)$ & 0.88 \\
\hline Abdominal fold present & $1(0.8)$ & $1(2.6)$ & - & 0.15 \\
\hline Acidotic breathing & $1(0.8)$ & $1(2.6)$ & - & 0.15 \\
\hline Nutritional status & & & & \\
\hline \multicolumn{5}{|c|}{ According to weight for age $(n, \%)$} \\
\hline Eutrophic & $35(26.7)$ & $10(26.3)$ & $25(26.9)$ & \\
\hline Light global UNT & $49(37.4)$ & $18(47.4)$ & $31(33.3)$ & \\
\hline Moderate global UNT & $41(31.3)$ & $9(23.7)$ & $32(34.4)$ & \\
\hline Severe global UNT & $6(4.6)$ & $1(2.6)$ & $5(5.9)$ & 0.94 \\
\hline
\end{tabular}


Table 1

General characteristics of children with HIVIAIDS infection. Hospital Universitario del Valle, Cali, Colombia 2008 ( $n=131)$ (continuation)

\begin{tabular}{|c|c|c|c|c|}
\hline & $\begin{array}{c}\text { All } \\
(n=131)\end{array}$ & $\begin{array}{c}\begin{array}{c}\text { Cases } \\
(\mathrm{n}=38)\end{array} \\
\text { C. spp. }+\end{array}$ & $\begin{array}{c}\text { Controls } \\
(n=93) \\
\text { C. spp. - }\end{array}$ & $\mathbf{p}$ \\
\hline \multicolumn{5}{|l|}{ According to height for age $(n, \%)$} \\
\hline Eutrophic & $48(36.6)$ & $16(42.1)$ & $32(34.4)$ & \\
\hline Light chronic UNT & $26(19.8)$ & $9(23.7)$ & $17(18.9)$ & \\
\hline Moderate chronic UNT & $40(30.5)$ & $11(28.9)$ & $29(31.2)$ & \\
\hline Severe chronic UNT & $17(12.98)$ & $2(5.26)$ & $15(16.13)$ & 0.40 \\
\hline According to weight for height $(n, \%)$ & $(n=126)$ & $(n=36)$ & $(n=90)$ & \\
\hline Eutrophic & $68(53.97)$ & $18(50)$ & $50(55.6)$ & \\
\hline Light acute UNT & $26(20.63)$ & $10(27.78)$ & $16(17.8)$ & \\
\hline Moderate acute UNT & $11(8.73)$ & $2(5.56)$ & $9(10.0)$ & \\
\hline Severe acute UNT & $2(1.59)$ & $1(2.78)$ & $1(1.1)$ & \\
\hline Overweight & $19(15.08)$ & $5(13.89)$ & $14(15.6)$ & 0.57 \\
\hline Prior hospitalizations $(\mathrm{n}, \%)$ & $102(77.86)$ & $33(86.84)$ & $69(74.2)$ & 0.11 \\
\hline Viral load (copies/ml) $(n, \%)$ & $(n=130)$ & $(n=38)$ & $(n=92)$ & \\
\hline$<400$ & 15 (11.54) & $4(10.53)$ & $11(11.9)$ & \\
\hline$\geq 400-<30,000$ & $26(20)$ & $9(23.68)$ & 17 (18.5) & \\
\hline$\geq 30,000-<100,000$ & $20(15.38)$ & $6(15.79)$ & $14(15.2)$ & \\
\hline$\geq 100,000$ & 69 (53.08) & $19(50)$ & $50(54.4)$ & 0.81 \\
\hline$\%$ CD4 (n,\%) & $(n=123)$ & $(n=37)$ & $(n=86)$ & \\
\hline$<15$ & $26(21.14)$ & $5(13.51)$ & $21(24.4)$ & \\
\hline$\geq 15-<25$ & $30(24.39)$ & $12(32.43)$ & $18(20.9)$ & \\
\hline$\geq 25$ & $67(54.47)$ & $20(54.05)$ & $47(54.6)$ & 0.17 \\
\hline \multicolumn{5}{|l|}{ Environmental variables $(n, \%)$} \\
\hline Household pets & $59(45.04)$ & $14(36.84)$ & $45(48.4)$ & 0.22 \\
\hline Overcrowding & $59(45.04)$ & $20(52.63)$ & 39 (41.9) & 0.26 \\
\hline Stay in day-care center & 55 (41.98) & $19(50)$ & $36(38.7)$ & 0.23 \\
\hline W/out potable water & $17(12.98)$ & $5(13.16)$ & $12(12.9)$ & 0.96 \\
\hline W/out excreta disposal & $13(9.98)$ & $4(10.53)$ & $9(9.7)$ & 0.88 \\
\hline
\end{tabular}

group of children with immune-compromise for HIV/ AIDS infection.

Upon comparing the current prevalence of $29 \%$ with the 51\% reported in 2006 by Siuffi et al. ${ }^{3}$, in the same population, we suggest this decrease in prevalence of infection may be due to several reasons, among others: different levels of precision due to different sample sizes; an over or under diagnosis by the bacteriologists in identifying Cryptosporidium spp. via the modified ZN technique; a spread use of HAART therapy that now diminishes the morbidity and mortality of superimposed infections, and possible seasonal changes at the moment of identifying Cryptosporidium spp. in feces. Regarding the identification of Cryptosporidium spp. via the modified ZN technique, in this study from the same sample of fecal matter we obtained three slides, which along with the poor sensitivity of the test -even when taking the three samples at different times, and the short duration of oocysts excretion of Cryptosporidium spp. ${ }^{16}$, may 
Table 2

Association between the presence of Cryptosporidium spp. and the socio-demographic, clinical, paraclinical, and environmental variables of children with HIVIAIDS infection.

Hospital Universitario del Valle, Cali, Colombia 2008

\begin{tabular}{llccccc}
\hline Socio-demographic variables & C. spp. + & C. spp. - & Odds Ratio & Cl 95\% & p \\
\hline Age groups & & & & & & \\
0-2 years & (Infant) & 8 & 34 & 1.00 & & \\
3-4 years & (Pre-school) & 9 & 26 & 1.47 & {$[0.49-4.33]$} & 0.48 \\
5-11 years & (School age) & 19 & 30 & 2.69 & {$[1.02-7.03]$} & 0.04 \\
12-14 years & (Adolescents) & 2 & 3 & 2.83 & {$[0.40-19.87]$} & 0.29 \\
Gender & & & & & & \\
Male & 19 & 50 & 1.00 & & 0.69 \\
Female & 19 & 43 & 0.86 & {$[0.40-1.83]$} & \\
Place of origin & 19 & 37 & 1.00 & & 0.22 \\
Cali & 9 & 31 & 0.56 & {$[0.22-1.42]$} & 0.59 \\
Valle & 10 & 25 & 0.77 & {$[0.31-1.95]$} & \\
Other & & & & &
\end{tabular}

Clinical Variables Nutritional status

according to PIAge (Global UNT)

\begin{tabular}{|c|c|c|c|c|c|}
\hline Eutrophic & 10 & 25 & 1.00 & & \\
\hline UNT I (deficit $\geq 10 \%-<25 \%$ ) & 18 & 31 & 1.45 & {$[0.56-3.69]$} & 0.43 \\
\hline UNT II (deficit $\geq 25 \%-<40 \%$ ) & 9 & 32 & 0.70 & [0.24-1.99] & 0.50 \\
\hline UNT III (deficit $\geq 40 \%$ ) & 1 & 5 & 0.50 & {$[0.05-4.83]$} & 0.54 \\
\hline \multicolumn{6}{|l|}{ Nutritional status according to } \\
\hline \multicolumn{6}{|l|}{ TIAge (Chronic UNT) } \\
\hline Eutrophic & 16 & 32 & 1.00 & & \\
\hline UNT I (deficit $\geq 5 \%-<10 \%$ ) & 9 & 17 & 1.05 & {$[0.38-2.89]$} & 0.91 \\
\hline UNT II (deficit $\geq 10 \%-<15 \%$ ) & 11 & 29 & 0.75 & [0.30-1.89] & 0.55 \\
\hline UNT III (deficit $\geq 15 \%$ ) & 2 & 15 & 0.26 & {$[0.05-1.31]$} & 0.10 \\
\hline \multicolumn{6}{|l|}{ Nutritional status according to } \\
\hline \multicolumn{6}{|l|}{$\begin{array}{l}\text { Weight/Height (Acute UNT } \\
\text { or overweight) }\end{array}$} \\
\hline Eutrophic & 18 & 50 & 1.00 & & \\
\hline UNT I (deficit 10\%-19\%) & 10 & 16 & 1.73 & {$[0.66-4.51]$} & 0.25 \\
\hline UNT II (deficit 20\%-\%) & 2 & 9 & 0.61 & [0.12-3.13] & 0.56 \\
\hline UNT III (deficit $\geq 30 \%$ ) & 1 & 1 & 2.77 & {$[0.16-46.77]$} & 0.47 \\
\hline Overweight (excess $\geq 10 \%$ ) & 5 & 14 & 0.99 & [0.31-3.14] & 0.98 \\
\hline \multicolumn{6}{|l|}{ Signs and symptoms } \\
\hline No & & 1 & & & \\
\hline Diarrhea & 3 & 13 & 0.68 & {$[0.17-2.64]$} & 0.58 \\
\hline Fever & 4 & 9 & 1.09 & [0.31-3.80] & 0.88 \\
\hline Abdominal pain & 5 & 14 & 0.85 & {$[0.28-2.56]$} & 0.78 \\
\hline
\end{tabular}


Table 2

Association between the presence of Cryptosporidium spp. and the socio-demographic, clinical, paraclinical, and environmental variables of children with HIVIAIDS infection. Hospital Universitario del Valle, Cali, Colombia 2008 (continuation)

\begin{tabular}{|c|c|c|c|c|c|}
\hline Socio-demographic variables & C. spp. + & C. spp. - & Odds Ratio & Cl 95\% & $\mathbf{p}$ \\
\hline Abdominal distension & 3 & 13 & 0.52 & {$[0.14-1.96]$} & 0.34 \\
\hline Dry oral mucosa & 2 & 2 & 2.52 & {$[0.34-18.63]$} & 0.36 \\
\hline Weeping without tears & 1 & 2 & 1.22 & {$[0.10-13.97]$} & 0.86 \\
\hline Vomit & 0 & 9 & 0.21 & {$[0.004-1.64]$} & 0.11 \\
\hline Enophthalmus & 0 & 2 & 0.78 & {$[0.01-10.16]$} & 0.83 \\
\hline Diminished distal perfusion & 0 & 1 & 1.19 & {$[0.01-23.49]$} & 0.88 \\
\hline Abdominal fold & 1 & 0 & 4.94 & [0.24-294.87] & 0.15 \\
\hline Acidotic breathing & 1 & 0 & 4.94 & {$[0.24-294.87]$} & 0.15 \\
\hline \multicolumn{6}{|l|}{ Stage } \\
\hline$A$ & 9 & 25 & 1.00 & & \\
\hline B & 6 & 27 & 0.61 & {$[0.19-1.98]$} & 0.41 \\
\hline C & 23 & 41 & 1.55 & {$[0.62-3.89]$} & 0.34 \\
\hline \multicolumn{6}{|l|}{ Hospitalizations } \\
\hline No & & 1 & & & \\
\hline Yes & 33 & 69 & 2.29 & {$[0.80-6.55]$} & 0.12 \\
\hline \multicolumn{6}{|l|}{ Paraclinical variables } \\
\hline \multicolumn{6}{|l|}{ Viral load (copies/ml) } \\
\hline$<400$ & 4 & 11 & 1.00 & & \\
\hline $400-29,999$ & 9 & 17 & 1.45 & {$[0.35-5.90]$} & 0.59 \\
\hline $30000-99,999$ & 6 & 14 & 1.17 & {$[0.26-5.23]$} & 0.82 \\
\hline$\geq 100,000$ & 19 & 50 & 1.04 & [0.29-3.68] & 0.94 \\
\hline \multicolumn{6}{|l|}{ Percentage CD4 (\%) } \\
\hline$<15$ & 5 & 21 & 1.00 & & \\
\hline $15-24$ & 12 & 18 & 2.80 & {$[0.82-9.46]$} & 0.09 \\
\hline$\geq 25$ & 20 & 47 & 1.78 & {$[0.59-5.40]$} & 0.30 \\
\hline \multicolumn{6}{|l|}{ Environmental variables } \\
\hline No & & 1 & & & \\
\hline Household pets & 14 & 45 & 0.62 & [0.28-1.34] & 0.23 \\
\hline Potable water & 33 & 81 & 0.97 & [0.31-2.99] & 0.96 \\
\hline Excreta disposal & 34 & 84 & 0.91 & {$[0.26-3.15]$} & 0.88 \\
\hline Overcrowding & 20 & 39 & 1.53 & {$[0.72-3.28]$} & 0.26 \\
\hline Stay in day care centers & 19 & 36 & 1.58 & {$[0.74-3.38]$} & 0.23 \\
\hline
\end{tabular}

explain the low prevalence we found in this study. To diminish the possible affectations in the validity of our study, perhaps due to information bias (poor classification), due to the number of samples to be evaluated (suggested minimum of two samples in patients with immune compromise as in the case of children with HIV/AIDS infection), we decided to identify Cryptosporidium spp. in three slides from a feces sample from each child.

The modified ZN technique was used in this study 
Table 3

Factors associated to Cryptosporidium spp. incidence according to the socio-demographic, clinical, and environmental variables of children with HIVIAIDS infection. Hospital Universitario del Valle, Cali, Colombia 2008 ( $N=131)$

\begin{tabular}{lccc}
\hline \multicolumn{1}{c}{ Variable } & Odds Ratio & Cl 95\% & p \\
\hline $\begin{array}{l}\text { Socio-demographic } \\
\quad \text { Age groups }\end{array}$ & 1.86 & {$[1.16-2.98]$} & 0.01 \\
Clinical & & & \\
$\quad$ Chronic UNT & 0.67 & {$[0.44-1.01]$} & 0.05 \\
$\quad$ Prior hospitalizations & 2.74 & {$[0.91-8.24]$} & 0.07 \\
$\quad$ Environmental & & & \\
$\quad$ Stay in day care centers & 2.11 & {$[0.92-4.85]$} & 0.07 \\
\hline
\end{tabular}

Table 4

Factors associated to Cryptosporidium spp. incidence according to the socio-demographic, clinical, and environmental variables of children with HIVIAIDS infection. Hospital Universitario del Valle, Cali, Colombia 2008 ( $N=122)$

\begin{tabular}{lccc}
\hline \multicolumn{1}{c}{ Variable } & Odds Ratio adjusted & Cl 95\% & p \\
\hline $\begin{array}{l}\text { Socio-demographic } \\
\text { Age groups }\end{array}$ & 1.79 & {$[1.12-2.86]$} & 0.01 \\
Clinical & & & \\
$\quad$ Chronic UNT & 0.63 & {$[0.41-0.96]$} & 0.03 \\
$\quad$ Prior hospitalizations & 2.62 & {$[0.85-8.04]$} & 0.09 \\
$\quad$ Environmental & & & \\
$\quad$ Stay in day care centers & 2.35 & {$[1.00-5.52]$} & 0.05 \\
\hline
\end{tabular}

because of its high specificity (100\%), although low sensitivity $(37 \%-77 \%)^{16-19}$. The test is relatively unknown by most physicians ${ }^{20}$ and many laboratories only analyze fecal samples for Cryptosporidium if requested by the clinician ${ }^{21}$. However, most health personnel believe cryptosporidiosis is a relatively rare disease, which is mainly caused by drinking water or exposure to swimming pools ${ }^{22}$.

The ZN diagnostic technique is troublesome because of the short period of oocyst excretion and the timeconsuming analysis procedure. Nevertheless, rapid techniques like immunoassays (ELISA) ${ }^{10}$ or direct immunofluorescence have limited use in epidemiological and diagnostic studies ${ }^{23}$. In consequence, and given that experimental data support that oocyst could be undetected by the ZN technique in $40-50 \%$ of individuals with diarrhea, we concentrated the samples by sporulation $^{24}$ and, subsequently, identified the oocysts by light microscopy ${ }^{25}$.

\section{Risk factors}

Age. Dankner et al. ${ }^{8}$ reported an age for acquiring cryptosporidiosis of 5.9 years. The average age of our patients was $4.8 \pm 3.4$ years (range: 1 month-14.4 years); while in the Cegielski et al., study it was 21 months $^{5}$ (range 15-51 months), in the Tumwine et al. study ${ }^{6}$ it was $14 \pm 9$ months, in the Guarino et al. paper ${ }^{7}$ it was 17 months (range 2-155 months), and in the study by Amadi et al. ${ }^{14}$, it was 18 months (range: $14-21$ months). In the statistical model of our study, older children were at higher risk of Cryptosporidium spp. OR=1.79 [CI $95 \% 1.12-2.86]$ ( $\mathrm{p}=0.01$ ); according to data previously reported by us $\mathrm{s}^{2,3}$, we hypothesize this is at least in part 
explained by this group of children being more exposed to parasite reservoirs

Gender. This study reports a slight predominance of the male gender over the female, at a ratio of 1.1 , as described in studies by Dankner et al. ${ }^{8}$ and Tumwine et $a l .{ }^{6}$, and unlike that observed by Cegielski et al. ${ }^{5}$ and Guarino et al. ${ }^{7}$; however, there are studies that do not manage to explain the gender differences regarding the presence of Cryptosporidium spp. ${ }^{12}$

Mode of transmission. This study revealed predominance of the vertical mode of transmission, as reported by Guarino et al. ${ }^{7}$, which according to Dankner et al. ${ }^{8}$, permits a better interpretation of the results, given that children infected through sexual contact later in life represent a population with a different duration of the infection. Our findings regarding mode of transmission are as expected, bearing in mind our own previous results $^{2,3}$ and that over $90 \%$ of the cases of HIV/AIDS infection in children is because of vertical transmission, from the mother to the child, during child birth (intrauterine), during labor, at delivery (intrapartum), or postnatal through maternal breastfeeding.

Viral load and percentage of CD4. The study's final statistical model did not include the viral load or the percentage of CD4 as risk factors in children with HIV/ AIDS infection to present Cryptosporidium spp.; data initially reported by us ${ }^{2,3}$, and unlike that described by Tumwine et al. ${ }^{6}$, who state that children low CD4 percentage $(\leq 15 \%)$ have 6.4 times the opportunity [CI 95\% 0.64-64.74 p=0.114] of presenting Cryptosporidium spp. than children with CD4 >15\%. Likewise, our data suggest in the univariate analysis that as CD4 percentage increases, the chances for Cryptosporidium spp. infection are lower: among children with \%CD4 $\geq 15$ and <25: OR=2.8 [CI 95\%: 0.82 - 9.46; $\mathrm{p}=0.09$ ]; and in those with \%CD4 $\geq 25$ : OR=1.78 [CI 95\% 0.595.40; $\mathrm{p}=0.30]$. This finding, apparently contradictory with the natural history of the disease, could be simply due to random effects or because our patients, unlike the children from Uganda ${ }^{6}$, received antiretroviral therapy, which could have favored increased percentage of CD4 and their better evolution. Our findings are paradoxical in that when our patients are included in the study, they presented in $53.1 \%$ of the cases viral loads over 100,000 copies/ml, meaning poor adherence to the HAART therapy. This does not agree with the results of CD4 percentage reported, which state the contrary.
This, we could probably interpret to the labile results of the viral load to the HAART therapy, especially bearing in mind that when the children were included in the study, the viral load used had been 15 days before or after taking the fecal matter sample. According to that reported by Dankner et al. ${ }^{8}$, in children with HIV infection and cryptosporidiosis, the mean \%CD4 was $4 \%$, while in our study this percentage was at $27 \pm 13 \%$ (range of 2-74\%); also, they reported the presence of 1.3 events per 100 individuals per year when the CD4 percentage is $<15 \%$ and 0.2 events per 100 individuals per year when the CD4 percentage is between 15-25\% and $\geq 25 \%$. In our case, over half of the children studied (54.47\%), presented a CD4 percentage $\geq 25 \%$.

Undernutrition. Upon comparing our results to that reported by Amadi et al. ${ }^{15}$, and Tumwine et al. ${ }^{6}$, who described severe acute undernutrition (UNT) in $22 \%$ of the cases, severe global UNT in $47 \%$, and severe chronic UNT in 63\%, our patients presented better nutritional conditions and we did not find nutritional status compromise of our patients in terms of severe UNT; only $1.6 \%$ of them presented severe acute UNT, $4.6 \%$ severe global UNT, and $13 \%$ severe chronic UNT, which permits us to conclude that the presence of Cryptosporidium spp. is associated to UNT. These data equally contradict that reported by Guarino et al. ${ }^{7}$ and Ceigielski et al. ${ }^{5}$ In general, we could assume that the nutritional status of the children from the study is acceptable, especially if compared with our prior data in this same group of children, who in 2005 presented global UNT in $72 \%$ of the cases, chronic UNT in $67 \%$, and acute UNT in 35\%, this is very probably secondary to the efficacy and effectiveness of the HAART therapy, and to the follow-up and control program at the HIV/ AIDS Pediatric Clinic at HUV, among others, which permit greater adherence to therapy and diminished morbidity and mortality in this group of children, which is outlined by their better nutritional status. The paradoxical protective effect found in our patients may be interpreted more than merely as chronic UNT, as being short stature for the age, whose causes are multifactorial and not only due to UNT; causes among which could be involved constitutional short stature, short family stature, constitutional retarded development, slow maturity, etc. In our particular case, and per se, because of the short stature reported in children due to the HIV/AIDS condition. It is also worth noting that 
the tables of reference used for the analysis of the nutritional status of our children were those from the United States National Center for Health and Statistics, given that these are universally considered in most of the studies reviewed and also because we used them previously in other studies ${ }^{2,3}$.

Hospitalizations. In the study Cegielski et al. ${ }^{5}$, hospital stay was significantly longer in the group of children with cryptosporidiosis (average of 10 days; range of 2-18 days) than in children without this infection (average of 4 days; range of $1-17$ days) $(p=0.03)$. In our study, children with prior hospitalizations have 2.75 times greater chance [CI 95\% 0.89-8.46 $\mathrm{p}=0.07$ ] of having Cryptosporidium spp., which could be explained not necessarily by what we would have expected, from the potential severity of enteric cryptosporidiosis in these types of patients, but rather, by the presence of coinfections due to other pathogens or co-morbidity from other conditions having to do with these types of patients, which were not considered for this study. We do not report any case of mortality during the study; however, Amadi et al. ${ }^{15}$, describe 3.3 greater opportunity of dying [CI 95\% 1.6-6.85 p=0.001] in children with Cryptosporidium spp. Again, the lack of deaths in our study may reflect the better nutritional status of the children included, better access to antiretroviral therapies and to the healthcare institution, and to adequate follow up within the HIV/AIDS Pediatric Clinic at HUV in Cali, Colombia, among others.

Signs and symptoms. For Cegielski et al. ${ }^{5}$ clinically, the distinctive findings were vomit and dehydration among children with acute diarrhea who had cryptosporidiosis; for us, fever [OR=1.09, (CI 95\% 0.31-3.80) $\mathrm{p}=0.88)]$, dry oral mucosa $[\mathrm{OR}=2.52$, (CI $95 \%$ 0.34-18.63) $\mathrm{p}=0.36$ ], and weeping without tears [OR=1.22, (CI95\% 0.10-13.97) $\mathrm{p}=0.86]$ were important findings, but they were, nevertheless, statistically insignificant. We only reported one child with dehydration, but Tumwine et al. ${ }^{6}$, describe $7.4 \%$ of their children with dehydration, and in their conclusions they even identify severe dehydration as a bad prognosis factor in children with HIV/AIDS infection and positive Cryptosporidium [OR 0.63 (CI 95\% 0.15-2.67) $\mathrm{p}=0.526]$, as reported by Guarino et al. ${ }^{7}$, who associate such dehydration to the secretor component and to the persistence of diarrhea secondary to Cryptosporidium.

Stage. Our patients were predominantly stage C, according to the classification from the United States Center for Disease Control (CDC), as that described by Guarino et al. ${ }^{7}$, but differing with their conclusions, because the evolution of our patients was satisfactory, while they not only found a clear association with the advanced stage of the HIV/AIDS infection but also with the rapid clinical and immunological compromise of their patients; suggesting for them that the severe disorder of the immune response is associated to colonization and subsequent clinical disease, which suggests them to propose that enteric cryptosporidiosis should be considered a key point in the progression of the HIV/AIDS infection.

Environmental. Cegielski et al. ${ }^{5}$ found no significant associations among household pets, crawling children, or walking children, or the type of or location of the bath or water. In our final statistical model, we found that children staying in day-care centers have 2.75 times greater opportunity [CI95\% 1.12-6.72p=0.02] of having Cryptosporidium spp.; this is because of the possibility of transmission among children attending day-care centers as secondary cases and asymptomatic infections among intra-family contacts; therein, the importance of keeping children with diarrhea from attending these daycare centers while they are sick.

Our recommendations are aimed at identifying the taxonomic characteristics of the parasite in our environment through high-resolution molecular epidemiology, which will help researchers to better understand its transmission in children and, thus, once characterized, associate it to the clinical manifestations of the different Cryptosporidium spp. species and subtypes. Although the highly active antiretroviral therapy (HAART) has reduced the incidence of the disease in children with HIV/AIDS infection, affecting the viral load, as well as the parasite load of Cryptosporidium spp., future studies could be guided towards the development of effective therapeutic agents and drug therapies for human cryptosporidiosis, particularly in patients with advanced immune compromise due to HIV/AIDS infection; thereby, diminishing their morbidity and mortality.

In conclusion, the prevalence of Colombian children with HIV/AIDS infection under HAART therapy was of $29 \%$, with the variables that best explained the presence of Cryptosporidium spp. included being older than two years of age, presenting chronic UNT with a deficit in height for age above $5 \%$, staying in day-care 
centers, and having been previously hospitalized.

Conflict of interests. The authors declare having no conflict of interests or conflicts with the institution where the research took place.

\section{REFERENCES}

1. Guerrant DI, Moore SR, Lima AA, Patrick PD, Schorling JB, Guerrant RL. Association of early childhood diarrhea and cryptosporidiosis with impaired physical fitness and cognitive function four-seven years later in a poor urban community in northeast Brazil. Am J Trop Med Hyg. 1999; 61: 707-13

2. Carreño M, Velasco CA, Rueda E. Prevalencia de Cryptosporidium spp. en niños menores de 13 años con afecciones oncológicas. Colomb Med. 2005; 36 (Supl 2): 6-9

3. Siuffi M, Angulo M, Velasco CA, López P, Dueñas VH, Rojas C. Relación entre los niveles de viral load y los niveles de linfocitos CD4 en el diagnóstico de Cryptosporidium spp. en heces de niños de la Clínica Pediátrica de VIH/SIDA del Hospital Universitario del Valle, Cali, Colombia. Colomb Med. 2006; 37: 15-20

4. Navarro L, da Silva A, Botero JH, Montoya MN, del Águila C, Bornay FJ. Cryptosporidiosis in HIV-positive patients from Medellin, Colombia. J Eukaryot Microbiol. 2006; 53 (Suppl 1): S37-S39.

5. Cegielski JP, Ortega YR, McKee S, Madden JF, Gaido L, Schwartz DA, et al., Cryptosporidium, Enterocytozoon, and Cyclospora infections in pediatric and adult patients with diarrhea in Tanzania. Clin Infect Dis. 1999; 28: 314-21.

6. Tumwine JK, Kekitiinwa A, Bakeera-Kitaka S, Ndeezi G, Downing R, Feng X, et al. Cryptosporidiosis and microsporidiosis in Ugandan children with persistent diarrhea with and without concurrent infection with the human immunodeficiency virus. Am J Trop Med Hyg. 2005; 73: 921-5.

7. Guarino A, Castaldo A, Russo S, Spagnuolo MI, Canani RB, Taralto L, et al. Enteric Cryptosporidiosis in pediatric HIV infection. J Pediatr Gastroenterol Nutr. 1997; 25: 182-7.

8. Dankner WM, Lindsey JC, Levin MJ. The Pediatric AIDS Clinical Trials Group. Correlates of opportunistic infections in children infected with the human immunodeficiency virus managed before highly active antiretroviral therapy. Pediatr Infect Dis J. 2001; 20: 40-8.

9. Mor SM, Tzipori S. Cryptosporidiosis in children in SubSaharan Africa: A lingering challenge. Clin Infect Dis. 2008; 47: 915-21.

10. De la Parte-Péreza MA, Bruzualb E, Britob A, Hurtado MP. Cryptosporidium spp. y criptosporidiosis. Rev Soc Ven Microbiol. 2005; 25: 6-14.

11. Sulaiman IM, Hira PR, Zhou L, Al-Ali FM, Al-Shelahi FA, Shweiki HM, et al. Unique endemicity of cryptosporidiosis in children in Kuwait. J Clin Microbiol. 2005; 43: 2805-9.

12. Bern C, Ortega Y, Checkley W, Roberts JM, Lescano AG, Cabrera L, et al. Epidemiologic differences between cyclosporiasis and cryptosporidiosis in Peruvian children. Emerg Infect Dis. 2002; 8: 581-5.

13. Nchito M, Kelly P, Sianongo S. Cryptosporidiosis in urban Zambian children: an analysis of risk factors. Am J Trop Med Hyg. 1998; 59: 435-7.

14. García LS, Bruckner DA, Brewer TC, Shimizu RY. Techniques for the recovery and identification of Cryptosporidium oocysts from stool specimens. J Clin Microbiol. 1983; 18: 185-90.

15. Amadi B, Kelly P, Mwiya M, Mulwazi E, Sianongo S, Changwe F, et al. Intestinal and systemic infection, HIV, and mortality in Zambian children with persistent diarrhea and malnutrition. J Pediatr Gastroenterol Nutr. 2001; 32: 550-4.

16. Weber R, Bryan RT, Bishop ES, Wahlquist SP, Sullivan JJ, Juranek DD. Threshold of detection of Cryptosporidium oocysts in human stool specimens: evidence for low sensitivity of current diagnostic methods. J Clin Microbiol. 1991; 29: 1323-7.

17. Kaushik K, Khurana S, Wanchu A, Malla N. Evaluation of staining techniques, antigen detection and nested PCR for the diagnosis of cryptosporidiosis in HIV seropositive and seronegative patients. Acta Tropica. 2008; 107: 1-7.

18. Xiaoa L, Ryan UM. Cryptosporidiosis: an update in molecular epidemiology. Curr Op Infect Dis. 2004; 17: 483-90.

19. Mclauchlin J, Amar CFL, Pedraza-Díaz S, Mieli-Vergani G, Hadzic N, Davies G. Polymerase chain reaction-based diagnosis of infection with Cryptosporidium in children with primary immunodeficiency. Pediatr Infect Dis J. 2003; 22: 329-34.

20. Morin CA, Roberts CL, Mshar PA, Addiss DG, Hadler JL. What do physicians know about cryptosporidiosis? A survey of Connecticut physicians. Arch Intern Med. 1997; 157: 101722.

21. Roberts CL, Morin C, Addiss DG, Wahlquist SP, Mshar PA, Hadler JL. Factors influencing Cryptosporidium testing in Connecticut. J Clin Microbiol. 1996; 34: 2292-3.

22. Doria MF, Abubakar I, Syed Q, Hughes S, Hunter PR. Perceived causes of sporadic cryptosporidiosis and their relation to sources of information. J Epidemiol Community Health. 2006; 60: 745-50.

23. Stazzone AM, Slaats S, Mortagy A, Kleinosky M, Diab A, Mourad A, et al. Frequency of Giardia and Cryptosporidium infections in Egyptian children as determined by conventional and immunofluorescence methods. Pediatr Infect Dis J. 1996; 15: 1044-6.

24. Huiza A, Espinoza Y, Rojas R. Detección de coccidios en niños asintomáticos mediante esporulación de muestras fecales. An Fac Med Lima. 2004; 65: 239-42.

25. Enriquez FJ, Avila CR, Santos JI, Tanaka-Judo J, Vallejo O, Sterling CR. Cryptosporidium infections in Mexican children: clinical, nutritional, enteropathogenic, and diagnostic evaluations. Am J Trop Med Hyg. 1997; 56: 254-7.

26. Iqbal J, Hira PR, Al-Ali R, Philip R. Cryptosporidiosis in Kuwaiti children: seasonality and endemicity. Clin Microbiol Infect. 2001; 7: 261-6. 